\title{
Incidence of Sclerotinia sclerotiorum and the physical and physiological quality of soybean seeds based on processing stages ${ }^{1}$
}

\author{
Heria de Freitas Teles ${ }^{2 *}$, Larissa Leandro Pires², Marcos Gomes da Cunha², \\ Flavio Pereira dos Santos ${ }^{2}$, Francisco Ameloti Neto ${ }^{2}$
}

\begin{abstract}
Soybean (Glycine max L. Merrill) is infected by a large number of fungal pathogens, among them white mold agent [Sclerotinia sclerotiorum (Lib) de Bary]. The objective of this study was to verify the effect of the seed-processing stages on the physical and physiological qualities and on the incidence of S. sclerotiorum in soybean seeds. In this study, seeds from eight cultivars coming from production fields naturally infested in the counties of the State of Goiás, Brazil, from two harvests (2009/2010 and 2010/2011), were used. Samples were collected in the processing stages: hopper, pre-cleaning, discard one (from pre-cleaning), cleaning, sieve classifiers, spiral, gravity table, and discard two (after cleaning until processing ending). The following parameters were evaluated: seed- moisture content, physical purity, germination and tetrazolium. Additional tests and the detection of S. sclerotiorum in paper roll and the neon method were performed. The processing of soybean seeds improves the physical and physiological quality of the seed lots, in addition to eliminating sclerotia. The stages of pre-cleaning and cleaning significantly reduce sclerotia in seed lot. The amount of sclerotia in the sample is not necessarily correlated with the incidence of $S$. sclerotiorum in mycelial form.
\end{abstract}

Index terms: white mold, physical purity, germination, seed health tests, neon method.

\section{Incidência de Sclerotinia sclerotiorum e qualidade física e fisiológica em função das etapas do beneficiamento de sementes de soja}

\begin{abstract}
RESUMO - A soja (Glycine max L. Merrill) é infectada por grande número de patógenos, entre eles o agente causal do mofobranco [Sclerotinia sclerotiorum (Lib) de Bary]. O objetivo deste trabalho foi verificar o efeito das etapas de beneficiamento nas qualidades física e fisiológica e na incidência de S. sclerotiorum em sementes de soja. Trabalhou-se com sementes de oito cultivares provenientes de campos de produção naturalmente infestados em municípios do Estado de Goiás, de duas safras. Foram coletadas amostras nas etapas do beneficiamento: moega, pré-limpeza, descarte um (da pré-limpeza), limpeza, classificadores de peneira, espiral, mesa de gravidade e descarte dois (após a limpeza até o final do beneficiamento). Realizaram-se análises de grau de umidade, pureza física, germinação e tetrazólio, além dos testes para a detecção de $S$. sclerotiorum em rolo de papel e método neon. O beneficiamento de sementes de soja aprimora as qualidades física e fisiológica do lote, além de eliminar os escleródios. As etapas de pré-limpeza e limpeza reduzem significativamente os escleródios das sementes. A quantidade de escleródios na amostra não está necessariamente correlacionada com a incidência de S. sclerotiorum na forma micelial.
\end{abstract}

Termos para indexação: mofo-branco, pureza física, germinação, teste de sanidade, método neon.

\section{Introduction}

Soybean (Glycine max L. Merrill) is currently one of the most important crops in the world. In Brazil, $40 \%$ of the total grain producing area was grown with this legume during the 2011/2012 crop season. The main producers were the states of Mato Grosso, Paraná, Rio Grande do Sul and Goiás (CONAB, 2012). One of the main problems of the crop has been white mold, which is caused by Sclerotinia sclerotiorum (Lib) de Bary. This disease is causing significant losses because besides for attacking more than 400 species, the pathogen may survive in soil for many years in the absence of hosts, by means of sclerotia (Bolton et al., 2006), which may be disseminated in several ways, including mixed to seeds (Tu, 1998). Besides the sanitary aspect, after harvest, the seeds may be mixed with impurities and other undesirable materials.

Submitted on 11/09/2012. Accepted for publication on 03/11/2013.

${ }^{2}$ Universidade Federal de Goiás, Escola de Agronomia, Caixa Postal 131, 74001-970 - Goiânia, GO, Brasil.

*Corresponding author: <heriafreitas@hotmail.com> 
Because of this, seed processing may be a useful tool for the control of $S$. sclerotiorum, reducing or eliminating the contaminated/infected seeds and the sclerotia associated with them. It may still improve the physical and physiological quality of the lot by separating the seeds from impurities.

A relationship between the physical properties of seeds and their viability and vigor makes the stages of separation and classification even more important in view of the fact that larger seeds may have superior germination and vigor than the smaller ones, as verified in soybean (Pádua et al., 2010) and fodder radish (Nery et al., 2009). The physiological quality may also be improved by the removal of lower density seeds, normally badly formed, broken, attacked by insects or pathogens or deteriorated (Fessel et al., 2003). Thus, it is important to use gravity table and air-screen machines in order to improve the physical, physiological, and sanitary conditions of the seed lots, as observed by Fessel et al. (2003) in corn, by Giomo et al. (2004) in arabica coffee and by Gadotti et al. (2006) in borecole broccolis.

The objective of this work was to analyze the effect of the processing stages in the physical and physiological qualities of the seed and in Sclerotinia sclerotiorum incidence in seeds of eight soybean cultivars.

\section{Material and Methods}

In this study, the soybean seeds that were used were produced in fields naturally infested by $S$. sclerotiorum, situated in Vianópolis, Silvânia, Luziânia and Orizona, State of Goiás, Brazil, from two crops seasons: 2009/2010 with five cultivars (NA 7255 RR, A 7002, NS 7476, AN 8500 and BRS Valiosa RR); and 2010/2011 with six cultivars (NA 7255 RR, NA 7337 RR, NA 7620 RR, NA 8015 RR, AN 8500 and BRS Valiosa RR).

In each flow stage in the Seed Processing Plant (SPP) a sample was collected (approximately $1.5 \mathrm{~kg}$ ) of seeds ( 14 samples total), as follows: 1- in hopper (reception); 2- after pre-cleaning; 3 - in discard one (from pre-cleaning); 4- after cleaning; 5 to 7after sieve classifiers (three sizes of sieves); 8 to 10 - after spiral (three sizes of sieves); 11 to 13- after gravity table (three sizes of sieves); and 14- in discard two (from stages after cleaning until seed processing ending). However, in the 2009/2010 crop season, seeds from cultivars NS 7476 and AN 8500 passed by only two sieve classifications and, in consequence, two classifications in spiral and two in gravity table.

The samples were homogenized, divided, and used as a working sample between $500 \mathrm{~g}$ to $515 \mathrm{~g}$. The following analyses were performed (Brasil, 2009b): moisture content, physical purity (count and weighing of sclerotia), germination and tetrazolium tests. For the detection of $S$. sclerotiorum, two methods were used (Brasil, 2009a): 1paper roll (four replications of 50 seeds) and 2- Neon or agarbromophenol medium (eight replications of 25 seeds), with some modification, using $75 \mathrm{mg} . \mathrm{L}^{-1}$ of bromophenol blue and 50 mg.L $\mathrm{L}^{-1}$ of chloramphenicol (Napoleão et al., 2006a). The bromophenol blue and the antibiotics were incorporated to the molten PDA medium $\left(50^{\circ} \mathrm{C}\right)$ after autoclaving. The Petri dishes were incubated in the dark at $18{ }^{\circ} \mathrm{C}$ for $7-12$ days with readings performed from day three.

The study of relations between the processing stages and the analyzed parameters was conducted by examining the correlation of those variables with the ordination axes generated by the multivariate analysis technique PCA (Principal Component Analysis). The PCA was performed from a mathematical matrix, correlating stages of processing (14) versus analyzed variables (8), by the statistical program PAST (Hammer et al., 2001). The variables included in the matrix were: moisture content, physical purity, sclerotia mass, germination, viability, vigor, sclerotia incidence by the sanitary analysis of paper roll and neon. The following procedures were recommended by Ter Braak (1986) and Palmer (1993), before the analysis was made the standardization of those variable values to mean zero and variance equal to unity, to remove disparities in the units of measurement of the different variables, so that all the variables had the same weight in the analysis (Hammer et al., 2001). Analyses of PCA were made for each cultivar in separate, generating ordination diagrams.

\section{Results and Discussion}

\section{Physical quality}

From reception in SPP until the evaluation moment, the moisture of seeds reduced from $13.4 \%$ to $8.2 \%$ in the $2009 / 2010$ crop season, and from $13.0 \%$ to $10.0 \%$ in the 2010/2011 crop season.

In both crop seasons, the physical purity varied from $17.23 \%$ to $100 \%$ with lower values in the samples from discarded one. Right after cleaning, it already had values over 99\%; exception to cultivar AN 8500 (crop season 2009/2010), with $97.85 \%$ in sample 4 (Table 1). According to Brazilian law, the minimum standard of physical purity for the commercialization of soybean seeds of certified (C1 and C2), S1 and S2 categories is 99\% (Brasil, 2005). It was noticed that, through seed processing, from the stages of pre-cleaning and cleaning (samples 2 and 4), it was possible to reach the minimum required standard, reaching $100 \%$ of physical purity in the final stage (after gravity table).

Air-screen machines (ASM), which were used in the precleaning and cleaning stages, improved the physical quality

Journal of Seed Science, v.35, n.4, p.409-418, 2013 
of the lots. Later, the association of classification equipment in sieves, spiral separator, and gravity table has standardized the seeds based on their physical characteristics. Nery et al. (2009) concluded that the association of ASM with gravity table is efficient for separating the fodder radish seed lots into fractions with different physical qualities.

Table 1. Physical purity (P.P.) and sclerotia mass (Scl.) in soybean (Glycine max) seeds, crops seasons 2009/2010 and 2010/2011, as a function of seed processing.

\begin{tabular}{|c|c|c|c|c|c|c|c|c|c|c|c|c|}
\hline \multicolumn{13}{|c|}{ Crop season $2009 / 2010$} \\
\hline \multirow{2}{*}{ Sample $^{1}$} & \multicolumn{3}{|c|}{ NA 7255 RR } & \multicolumn{2}{|c|}{ A 7002} & \multicolumn{2}{|c|}{ NS 7476} & \multicolumn{3}{|c|}{ AN 8500} & \multicolumn{2}{|c|}{ BRS Valiosa RR } \\
\hline & P.P. (\%) & \multicolumn{2}{|c|}{ Scl. (g) } & P.P. (\%) & \multirow{2}{*}{ Scl. (g) } & \multirow{2}{*}{$\begin{array}{c}\text { P.P. (\%) } \\
98.13\end{array}$} & \multirow{2}{*}{$\begin{array}{l}\text { Scl. (g) } \\
0.3186\end{array}$} & P.P. (\%) & \multicolumn{2}{|c|}{ Scl. (g) } & P.P. (\%) & Scl. (g) \\
\hline 1 & 96.89 & \multicolumn{2}{|c|}{0.0111} & 96.83 & & & & 97.96 & \multicolumn{2}{|c|}{0.0576} & 96.28 & 0.0970 \\
\hline 2 & \multirow{2}{*}{$\begin{array}{l}99.82 \\
23.91\end{array}$} & \multicolumn{2}{|c|}{0.0000} & 99.65 & 0.0513 & 99.41 & 0.0000 & 99.64 & \multicolumn{2}{|c|}{0.0000} & 99.32 & 0.0000 \\
\hline 3 & & 1.07 & & 0.29 & 0.7899 & 34.62 & 1.9444 & 75.00 & 1.19 & & 24.85 & 0.2235 \\
\hline 4 & 99.91 & 0.00 & & 9.61 & 0.0000 & 99.94 & 0.0000 & 97.85 & 0.00 & & 99.92 & 0.0000 \\
\hline 5 & 99.94 & 0.00 & & 9.85 & 0.0000 & 99.96 & 0.0000 & 99.62 & 0.00 & & 99.96 & 0.0000 \\
\hline 6 & 99.89 & 0.00 & & 9.83 & 0.0000 & 99.96 & 0.0000 & 99.43 & 0.02 & & 99.91 & 0.0000 \\
\hline 7 & 99.72 & 0.00 & & 9.72 & 0.0000 & - & - & - & - & & 99.87 & 0.0000 \\
\hline 8 & 100.00 & 0.00 & & 9.96 & 0.0000 & 99.97 & 0.0000 & 99.80 & 0.00 & & 99.96 & 0.0000 \\
\hline 9 & 99.93 & 0.00 & & 9.95 & 0.0000 & 99.98 & 0.0000 & 99.91 & 0.00 & & 100.00 & 0.0000 \\
\hline 10 & 99.78 & 0.00 & & 9.75 & 0.0000 & - & - & - & - & & 99.99 & 0.0000 \\
\hline 11 & 100.00 & 0.00 & & 0.00 & 0.0000 & 100.00 & 0.0000 & 99.97 & 0.00 & & 100.00 & 0.0000 \\
\hline 12 & 100.00 & 0.00 & & 9.99 & 0.0000 & 100.00 & 0.0000 & 99.98 & 0.00 & & 100.00 & 0.0000 \\
\hline 13 & 100.00 & 0.00 & & 0.00 & 0.0000 & - & - & - & - & & 99.99 & 0.0000 \\
\hline 14 & 98.91 & 0.20 & & 7.82 & 0.1515 & 99.24 & 0.0000 & 93.79 & 0.00 & & 96.38 & 0.1450 \\
\hline Average $^{2}$ & 99.65 & 0.00 & & 9.59 & 0.0280 & 99.70 & 0.0354 & 99.35 & 0.00 & & 99.60 & 0.0081 \\
\hline & & & & & & son 201 & $/ 2011$ & & & & & \\
\hline Sample 1 & NA 725 & $55 \mathrm{RR}$ & NA 73 & $37 \mathrm{RR}$ & NA 76 & $20 \mathrm{RR}$ & NA 80 & $15 \mathrm{RR}$ & AN 8 & 3500 & BRS Va & liosa RR \\
\hline sample & P.P. (\%) & Scl. (g) & P.P. (\%) & Scl. (g) & P.P. (\%) & Scl. (g) & P.P. (\%) & Scl. (g) & P.P. (\%) & Scl. (g) & P.P. (\%) & Scl. (g) \\
\hline 1 & 98.99 & 0.0293 & 98.52 & 0.0454 & 97.40 & 5.1687 & 97.97 & 0.5812 & 96.67 & 1.2277 & 98.22 & 0.0382 \\
\hline 2 & 99.29 & 0.0000 & 99.86 & 0.0000 & 99.43 & 0.0000 & 99.52 & 0.0000 & 99.37 & 0.0565 & 99.37 & 0.0000 \\
\hline 3 & 20.93 & 0.5851 & 17.23 & 0.2468 & 17.60 & 27.8000 & 24.57 & 10.0099 & 50.09 & 12.3936 & 23.03 & 1.0560 \\
\hline 4 & 99.60 & 0.0000 & 99.62 & 0.0000 & 99.80 & 0.0000 & 99.74 & 0.0000 & 99.71 & 0.0000 & 99.96 & 0.0000 \\
\hline 5 & 99.89 & 0.0000 & 99.32 & 0.0000 & 98.97 & 0.0000 & 99.72 & 0.0000 & 99.94 & 0.0000 & 99.97 & 0.0000 \\
\hline 6 & 99.82 & 0.0000 & 99.88 & 0.0000 & 99.80 & 0.0000 & 99.85 & 0.0000 & 99.80 & 0.0000 & 99.96 & 0.0000 \\
\hline 7 & 99.68 & 0.0000 & 99.82 & 0.0000 & 99.84 & 0.0000 & 99.85 & 0.0000 & 99.13 & 0.0000 & 99.98 & 0.0000 \\
\hline 8 & 99.91 & 0.0000 & 99.94 & 0.0000 & 99.95 & 0.0000 & 99.83 & 0.0000 & 99.99 & 0.0000 & 100.00 & 0.0000 \\
\hline 9 & 99.95 & 0.0000 & 99.98 & 0.0000 & 100.00 & 0.0000 & 99.96 & 0.0000 & 99.93 & 0.0000 & 100.00 & 0.0000 \\
\hline 10 & 99.90 & 0.0000 & 99.96 & 0.0000 & 99.94 & 0.0000 & 99.91 & 0.0000 & 99.91 & 0.0000 & 100.00 & 0.0000 \\
\hline 11 & 100.00 & 0.0000 & 99.97 & 0.0000 & 99.88 & 0.0000 & 99.96 & 0.0000 & 99.98 & 0.0000 & 100.00 & 0.0000 \\
\hline 12 & 99.99 & 0.0000 & 100.00 & 0.0000 & 100.00 & 0.0000 & 100.00 & 0.0000 & 99.87 & 0.0000 & 100.00 & 0.0000 \\
\hline 13 & 100.00 & 0.0000 & 100.00 & 0.0000 & 100.00 & 0.0000 & 99.99 & 0.0000 & 99.90 & 0.0000 & 100.00 & 0.0000 \\
\hline 14 & 91.98 & 0.1596 & 97.29 & 0.0000 & 96.60 & 0.0460 & 97.20 & 0.0000 & 97.54 & 0.1557 & 98.95 & 0.0000 \\
\hline Average $^{2}$ & 99.75 & 0.0024 & 99.74 & 0.0038 & 99.58 & 0.4307 & 99.69 & 0.0484 & 99.51 & 0.1070 & 99.79 & 0.0032 \\
\hline
\end{tabular}

${ }^{1} 1$-hopper; 2 -after pre-cleaning; 3-discard one; 4-after cleaning; 5 to 7 -after sieve classifiers; 8 to 10 -after spiral separator; 11 to 13 -after gravity table; 14 discard two; ${ }^{2}$ not considering the samples from discard (3 and 14$)$.

The presence of sclerotia was observed during the first stage of seed processing (hopper) and in samples from the discard one stage in all cultivars, and in discard two for $54.4 \%$ of them, in both crop seasons. The higher amount of sclerotia in discard one demonstrates the importance of pre-cleaning. It was found between two to 201 sclerotia $(0.1110 \mathrm{~g}$ to $1.9444 \mathrm{~g})$, and between one to more than 3,000 sclerotia ( $0.0293 \mathrm{~g}$ to $27.800 \mathrm{~g}$ ) by sample, in the 2009/2010 and 2010/2011 crop seasons, respectively. After pre-cleaning, associated to cleaning, no sclerotia were found, with the exception of sample six from cultivar AN 8500 (Table 1).

This work showed that sclerotia were totally removed during seed processing (Table 1), demonstrating that this process is a useful tool to control S. sclerotiorum and, in consequence, to reduce the amount of inoculum that might be introduced in new planting areas. Napoleão et al. (2006b), working with two cultivars of bean seeds, found 389 sclerotia in residues from cultivar Diamante Negro and 91 in bean cultivar Pérola. According to the author, this greater amount of sclerotia 
in Diamante Negro, because this is an erect bearing variety whose pods rarely touch the ground and it does not differ from plants, and the sclerotia are taken together with the pods for processing.

If white mold in soybean is considered a predominantly monocyclic disease, that is, only the initial inoculum is responsible for the amount of disease (Vanderplank, 1963), proper seed processing may represent an important step to reduce this inoculum and, in consequence, the disease incidence in the field.

\section{Physiological quality}

Considering the seed processing stages, except discards (samples 3 and 14), during the 2009/2010 crop season, the seeds had lower germination, viability and vigor than during the 2010/2011 crop season (Table 2). However, the average values of germination are acceptable, according to Brazilian seed law (2003), where the minimum standard for the commercialization of soybeans from the certified, $\mathrm{S} 1$, and S2 categories is $80 \%$ (Brasil, 2005). Overall, among the processing stages and among the cultivars, the germination percentages were lower than the viability ones according to the tetrazolium test, probably due to the presence of fungi, such as Phomopsis spp. and Fusarium semitectum. According to França-Neto et al. (1998) differences are acceptable to $5 \%$ between the viability test by the tetrazolium and germination test.

An opposite behavior was observed in cultivars A 7002 and BRS Valiosa RR (crop season 2009/2010), the germination percentages were higher than those of viability by the tetrazolium test. In both cultivars there was an increase of the vigor percentage with processing, which was not observed in other cultivars, in both crop seasons (Table 2).

The physical properties may be related to the viability and vigor of seeds, as verified by Pádua et al. (2010) in soybean seeds, and by Perin et al. (2002) in bean seeds, reported that small seeds reduced the stand of cultivar Carioca. Differently, Costa et al. (2004) concluded that the physiological quality is not affected by the size of soybean seeds. In this work, larger seeds had germination and vigor superior to smaller ones and in some cultivars and after some processing stages: AN 8500 (spiral separator and gravity table) and NS 7476 (gravity table) during the crop season 2009/2010; NA 7255 RR and NA 7337 RR (gravity table), NA 7620 RR, AN 8500 and BRS Valiosa RR (gravity table only for variable vigor) in the crop season 2010/2011 (Table 2). For most of the cultivars, seeds with higher density had more vigor after the gravity table stage.

Giomo et al. (2004) related that it is important to remove less dense seeds from the lot, because their small amount of reserve substances may lead to a slow growth of seedlings. The exclusive use of ASM did not improve the lot of seeds quality, but associated to gravity table, there was efficiency in the separation and distribution of superior quality portions in Vigna unguiculata (Mertz et al., 2007) and in coffee (Giomo et al., 2008).

The results of the tetrazolium test (level 1-8), notes that the damage caused to the seeds were higher in the 2009/2010 crop season (average of 22.3\%) compared to 2010/2011 (average of $17.2 \%$ ), especially those damaged by stinkbugs in both crop seasons, being, on average, $22.0 \%$, followed by mechanical $(20.2 \%)$ and by moisture $(17.1 \%)$. Among the cultivars, the values of damage varied from $10.0 \%$ to $32.0 \%$ (mechanical), from $9.8 \%$ to $37.0 \%$ (stinkbugs) and from $3.5 \%$ to $32.0 \%$ (by moisture).

\section{Sclerotinia sclerotiorum incidence}

The incidence of $S$. sclerotiorum in seeds was not detected in cultivars A 7002 and BRS Valiosa RR (crop season 2009/2010) by any of the methods. There was also a difference between the method results with regard to the evaluation of fungus incidence. In the 2009/2010 crop season, for the same cultivar, a greater incidence of fungus was found by neon; the opposite happened during the 2010/2011 crop season, when the larger incidence was obtained by paper roll, with the exception of cultivar NA 7255 RR. In additon, there were situations where the incidence was detected only by paper roll (NA 7337 RR, NA 8015 RR and BRS Valiosa RR - crop season 2010/2011) and by neon only (AN 8500 - crop season 2009/2010) (Table 3).

The neon method is quicker, but the execution is more laborious and costly. The paper roll has a longer incubation period, but a lower cost and simpler execution. However, it may also overestimate the fungus incidence because of cross contamination among seeds. The higher incidences of fungus were obtained in samples from discard (3 and 14), followed by the one from hopper (sample 1). Regardless of the processing stage, the cultivars had different percentages of infection among themselves, varying from $0.0 \%$ to $9.0 \%$ (crop season $2009 / 2010$ ) and from $0.0 \%$ to $25.0 \%$ - samples from discard (crop season 2010/2011), by the paper roll method; as for neon, this percentage varied from $0.0 \%$ to $5.5 \%$ and from $0.0 \%$ to $5.0 \%$, respectively (Table 3 ). This difference between cultivars may be due to factors related to the different production fields, chemical control, if used, as well as the efficiency of the fungicides applied, field localization and planting density (stand).

Incidence of S. sclerotiorum was observed in samples 11, 12 and 13 of some cultivars (Table 3). According to Tu (1998), the mycelium may keep its viability by more than three years. Many contaminated seeds may not germinate, but may still produce mycelium and sclerotia. Therefore, it is important 
not only for sclerotia quantification by purity analysis, whose the seed health test to detect the presence of the pathogen as standard of tolerance is zero, but also for the sensitivity of dormant mycelium in the seeds.

Table 2. Germination percentage (G.), viability (Vb.) and vigor (Vg.) of soybean (Glycine max), crops seasons 2009/2010 and 2010/2011, on seed-processing stages.

\begin{tabular}{|c|c|c|c|c|c|c|c|c|c|c|c|c|c|c|c|c|c|c|}
\hline \multicolumn{19}{|c|}{ Crop season $2009 / 2010$} \\
\hline \multirow{2}{*}{ Sample $^{1}$} & \multicolumn{3}{|c|}{ NA 7255 RR } & \multicolumn{4}{|c|}{ A 7002} & \multicolumn{3}{|c|}{ NS 7476} & & \multicolumn{3}{|c|}{ AN 8500} & \multicolumn{4}{|c|}{ BRS Valiosa RR } \\
\hline & G. & $\mathrm{Vb}$. & Vg. & G. & \multicolumn{2}{|c|}{$\mathrm{Vb}}$. & Vg. & G. & $\mathrm{Vb}$. & $\mathrm{Vg}$ & & G. & $\mathrm{Vb}$. & Vg. & G. & \multicolumn{2}{|c|}{$\mathrm{Vb}}$. & Vg. \\
\hline 1 & 82.0 & 84.0 & 74.0 & 80.0 & \multicolumn{2}{|c|}{80.0} & 72.0 & 73.5 & 79.0 & 73. & & 77.5 & 84.0 & 74.0 & 83.0 & \multicolumn{2}{|c|}{80.0} & 60.0 \\
\hline 2 & 84.0 & 84.0 & 80.0 & 82.0 & \multicolumn{2}{|c|}{85.0} & 74.0 & 76.0 & 80.0 & 75 . & & 80.5 & 89.0 & 83.0 & 83.0 & \multicolumn{2}{|c|}{78.0} & 63.0 \\
\hline 3 & 40.0 & 52.0 & 36.0 & 71.0 & \multicolumn{2}{|c|}{81.0} & 63.0 & 36.0 & 40.0 & 35. & & 31.0 & 61.0 & 49.0 & 20.5 & \multicolumn{2}{|c|}{22.0} & 10.0 \\
\hline 4 & 74.0 & 77.0 & 64.0 & 85.5 & \multicolumn{2}{|c|}{85.0} & 74.0 & 75.0 & 82.0 & 65. & & 70.5 & 74.0 & 65.0 & 83.0 & \multicolumn{2}{|c|}{73.0} & 60.0 \\
\hline 5 & 79.0 & 80.0 & 64.0 & 89.0 & \multicolumn{2}{|c|}{84.0} & 70.0 & 71.0 & 79.0 & 67. & & 71.0 & 82.0 & 74.0 & 82.0 & \multicolumn{2}{|c|}{78.0} & 61.0 \\
\hline 6 & 79.0 & 80.0 & 60.0 & 88.0 & \multicolumn{2}{|c|}{85.0} & 70.0 & 77.0 & 81.0 & 64. & & 77.5 & 85.0 & 70.0 & 79.5 & \multicolumn{2}{|c|}{72.0} & 59.0 \\
\hline 7 & 74.5 & 80.0 & 60.0 & 87.0 & 87 & 80 & 75.0 & - & - & - & & - & - & - & 83.5 & 81. & & 60.0 \\
\hline 8 & 79.5 & 77.0 & 60.0 & 85.5 & 85 & .0 & 70.0 & 75.5 & 84.0 & 69. & & 72.5 & 85.0 & 74.0 & 79.0 & 75. & & 69.0 \\
\hline 9 & 79.5 & 81.0 & 60.0 & 91.0 & 84 & 1.0 & 70.0 & 77.0 & 82.0 & 65. & & 78.5 & 89.0 & 80.0 & 85.5 & 85. & & 62.0 \\
\hline 10 & 81.5 & 81.0 & 61.0 & 89.0 & 83 & .0 & 78.0 & - & - & - & & - & - & - & 85.0 & 86. & & 66.0 \\
\hline 11 & 75.0 & 80.0 & 61.0 & 87.0 & 85 & .0 & 73.0 & 76.5 & 83.0 & 61. & & 77.5 & 82.0 & 70.0 & 86.5 & 81. & & 69.0 \\
\hline 12 & 79.5 & 83.0 & 64.0 & 87.0 & 90 & .0 & 78.0 & 76.5 & 87.0 & 66. & & 82.5 & 87.0 & 78.0 & 87.5 & 79. & & 68.0 \\
\hline 13 & 73.5 & 79.0 & 61.0 & 82.5 & 90 & .0 & 77.0 & - & - & - & & - & - & - & 85.5 & 80 . & & 70.0 \\
\hline 14 & 48.0 & 60.0 & 43.0 & 68.0 & 66 & 5.0 & 44.0 & 49.5 & 42.0 & 39. & & 57.5 & 80.0 & 57.0 & 72.5 & 51. & & 33.0 \\
\hline Average $^{2}$ & 78.4 & 80.5 & 64.1 & 86.1 & 85 & .3 & 73.4 & 75.3 & 81.9 & 67. & & 76.4 & 84.1 & 74.2 & 83.6 & 79. & & 63.9 \\
\hline $\begin{array}{l}\text { Overall } \\
\text { average }^{3}\end{array}$ & Germ. & 80.0 & & Viab. & 82 & .2 & & Vigor & 68.6 & & & & - & & & & - & \\
\hline & & & & & & & Crop s & season 2 & $010 / 20$ & & & & & & & & & \\
\hline Sample 1 & NA & 7255 & & NA & $7337 \mathrm{~F}$ & & & $7620 \mathrm{~F}$ & & & 8015 & RR & & AN 850 & & BRS & Valio & sa RR \\
\hline Sапиріс & G. & Vb. & Vg. & G. & $\mathrm{Vb}$. & Vg. & G. & $\mathrm{Vb}$. & Vg. & G. & $\mathrm{Vb}$. & Vg. & G. & $\mathrm{Vb}$. & Vg. & G. & $\mathrm{Vb}$. & Vg. \\
\hline 1 & 82.5 & 92.0 & 82.0 & 86.0 & 99.0 & 90.0 & 80.0 & 95.0 & 89.0 & 87.5 & 85.0 & 72.0 & 87.0 & 87.0 & 84.0 & 84.5 & 83.0 & 75.0 \\
\hline 2 & 87.5 & 88.0 & 86.0 & 83.5 & 98.0 & 94.0 & 79.5 & 87.0 & 83.0 & 84.0 & 90.0 & 76.0 & 87.5 & 89.0 & 81.0 & 81.0 & 84.0 & 71.0 \\
\hline 3 & 33.0 & 40.0 & 30.0 & 36.5 & 49.0 & 39.0 & 20.0 & 36.0 & 23.0 & 32.5 & 34.0 & 15.0 & 65.0 & 67.0 & 53.0 & 28.0 & 37.0 & 20.0 \\
\hline 4 & 86.0 & 94.0 & 87.0 & 81.5 & 92.0 & 80.0 & 85.0 & 93.0 & 85.0 & 84.0 & 94.0 & 83.0 & 84.0 & 96.0 & 86.0 & 84.5 & 89.0 & 77.0 \\
\hline 5 & 85.0 & 90.0 & 84.0 & 86.0 & 86.0 & 74.0 & 84.5 & 93.0 & 86.0 & 86.5 & 93.0 & 83.0 & 86.0 & 93.0 & 85.0 & 90.0 & 97.0 & 84.0 \\
\hline 6 & 83.5 & 89.0 & 82.0 & 80.5 & 90.0 & 81.0 & 88.0 & 91.0 & 87.0 & 87.5 & 88.0 & 77.0 & 83.5 & 97.0 & 85.0 & 87.5 & 89.0 & 75.0 \\
\hline 7 & 87.0 & 89.0 & 83.0 & 89.0 & 94.0 & 81.0 & 89.5 & 93.0 & 87.0 & 81.0 & 89.0 & 76.0 & 84.5 & 93.0 & 87.0 & 85.5 & 94.0 & 78.0 \\
\hline 8 & 84.5 & 88.0 & 81.0 & 83.5 & 90.0 & 77.0 & 80.0 & 93.0 & 75.0 & 84.0 & 86.0 & 80.0 & 85.5 & 92.0 & 82.0 & 88.5 & 90.0 & 73.0 \\
\hline 9 & 82.0 & 89.0 & 83.0 & 86.5 & 93.0 & 84.0 & 87.0 & 90.0 & 87.0 & 82.5 & 90.0 & 80.0 & 81.0 & 91.0 & 81.0 & 85.5 & 92.0 & 78.0 \\
\hline 10 & 89.0 & 89.0 & 78.0 & 80.5 & 99.0 & 89.0 & 85.0 & 88.0 & 80.0 & 86.0 & 89.0 & 81.0 & 82.0 & 91.0 & 84.0 & 88.0 & 88.0 & 75.0 \\
\hline 11 & 88.5 & 88.0 & 80.0 & 81.0 & 87.0 & 79.0 & 82.0 & 83.0 & 70.0 & 86.0 & 81.0 & 72.0 & 84.0 & 90.0 & 80.0 & 85.0 & 89.0 & 74.0 \\
\hline 12 & 88.0 & 88.0 & 83.0 & 82.5 & 94.0 & 80.0 & 90.0 & 90.0 & 85.0 & 89.5 & 96.0 & 81.0 & 83.0 & 92.0 & 84.0 & 88.5 & 91.0 & 78.0 \\
\hline 13 & 90.0 & 90.0 & 89.0 & 89.5 & 96.0 & 81.0 & 87.5 & 90.0 & 87.0 & 83.5 & 93.0 & 72.5 & 81.0 & 90.0 & 87.0 & 85.5 & 89.0 & 80.0 \\
\hline 14 & 66.5 & 70.0 & 66.0 & 67.5 & 66.0 & 46.0 & 81.0 & 90.0 & 80.0 & 70.5 & 72.0 & 49.0 & 75.5 & 88.0 & 78.0 & 77.5 & 82.0 & 62.0 \\
\hline Average $^{2}$ & 86.1 & 89.5 & 83.2 & 84.2 & 93.2 & 82.5 & 84.8 & 90.5 & 83.4 & 85.2 & 89.5 & 77.8 & 84.1 & 91.8 & 83.8 & 86.2 & 89.6 & 76.5 \\
\hline $\begin{array}{l}\text { Overall } \\
\text { average }^{3}\end{array}$ & Germ. & 85.1 & & Viab. & 90.7 & & Vigor & 81.2 & & & - & & & - & & & - & \\
\hline
\end{tabular}

11-hopper; 2-after pre-cleaning; 3-discard one; 4-after cleaning; 5 to 7-after sieve classifiers; 8 to 10-after spiral; 11 to 13-after gravity table; 14- discard two; ${ }^{2}$ not considering the samples from discard (3 and 14); ${ }^{3}$ considering samples from all cultivars, except samples from discard (3 and 14). 
Table 3. Incidence (\%) of Sclerotinia sclerotiorum, detected by seed health tests in the paper roll (PR) and neon method (Neon), in soybean (Glycine $\max$ ) seeds, crop seasons 2009/2010 and 2010/2011, on the seed-processing stages.

\begin{tabular}{|c|c|c|c|c|c|c|c|c|c|c|c|c|}
\hline \multicolumn{13}{|c|}{ Crop season 2009/2010 } \\
\hline \multirow{2}{*}{ Sample $^{1}$} & \multicolumn{3}{|c|}{ NA 7255 RR } & \multicolumn{2}{|c|}{ A 7002} & \multicolumn{2}{|c|}{ NS 7476} & \multicolumn{2}{|c|}{ AN 8500} & \multicolumn{3}{|c|}{ BRS Valiosa RR } \\
\hline & \multicolumn{2}{|c|}{ PR } & Neon & PR & \multirow{2}{*}{$\begin{array}{c}\text { Neon } \\
0.0\end{array}$} & PR & Neon & \multirow{2}{*}{$\begin{array}{l}\text { PR } \\
0.0\end{array}$} & Neon & \multicolumn{2}{|r|}{ PR } & Neon \\
\hline 1 & \multicolumn{2}{|c|}{0.5} & 1.5 & 0.0 & & 0.5 & 0.5 & & 1.0 & & 0.0 & 0.0 \\
\hline 2 & \multicolumn{2}{|c|}{0.5} & 0.0 & 0.0 & 0.0 & 0.0 & 0.0 & 0.0 & 0.0 & & 0.0 & 0.0 \\
\hline 3 & \multicolumn{2}{|c|}{3.0} & 3.0 & 0.0 & 0.0 & 1.0 & 3.0 & 0.0 & 0.0 & & 0.0 & 0.0 \\
\hline 4 & & & 0.0 & 0.0 & 0.0 & 0.5 & 0.5 & 0.0 & 0.0 & & 0.0 & 0.0 \\
\hline 5 & & & 0.0 & 0.0 & 0.0 & 0.0 & 0.5 & 0.0 & 0.0 & & 0.0 & 0.0 \\
\hline 6 & & & 0.0 & 0.0 & 0.0 & 0.0 & 0.5 & 0.0 & 0.0 & & 0.0 & 0.0 \\
\hline 7 & & & 0.0 & 0.0 & 0.0 & - & - & - & - & & 0.0 & 0.0 \\
\hline 8 & & & 0.0 & 0.0 & 0.0 & 0.0 & 1.5 & 0.0 & 0.0 & & 0.0 & 0.0 \\
\hline 9 & & & 0.0 & 0.0 & 0.0 & 0.0 & 1.5 & 0.0 & 1.5 & & 0.0 & 0.0 \\
\hline 10 & & & 0.0 & 0.0 & 0.0 & - & - & - & - & & 0.0 & 0.0 \\
\hline 11 & & & 0.0 & 0.0 & 0.0 & 0.0 & 1.5 & 0.0 & 1.0 & & 0.0 & 0.0 \\
\hline 12 & & & 0.0 & 0.0 & 0.0 & 0.0 & 2.5 & 0.0 & 1.5 & & 0.0 & 0.0 \\
\hline 13 & & & 0.0 & 0.0 & 0.0 & - & - & - & - & & 0.0 & 0.0 \\
\hline 14 & & & 0.0 & 0.0 & 0.0 & 0.0 & 5.5 & 0.0 & 0.0 & & 0.0 & 0.0 \\
\hline Overage $^{2}$ & & & 0.13 & 0.0 & 0.0 & 0.11 & 1.00 & 0.00 & 0.44 & & 0.0 & 0.0 \\
\hline & & & & & Crop s & son 2010 & 011 & & & & & \\
\hline Sample1 & NA & $5 \mathrm{RR}$ & NA & 337 RR & $\mathrm{NA}$ & $20 \mathrm{RR}$ & NA & $5 \mathrm{RR}$ & AN & 500 & BRS & liosa RR \\
\hline Sample & PR & Neon & PR & Neon & PR & Neon & $\mathrm{PR}$ & Neon & PR & Neon & PR & Neon \\
\hline 1 & 1.0 & 0.0 & 0.5 & 0.0 & 10.5 & 0.0 & 3.5 & 0.0 & 1.0 & 0.0 & 2.0 & 0.0 \\
\hline 2 & 0.0 & 5.0 & 3.0 & 0.0 & 0.0 & 1.5 & 1.0 & 0.0 & 0.5 & 0.0 & 2.5 & 0.0 \\
\hline 3 & 2.5 & 3.0 & 9.0 & 0.0 & 2.5 & 4.0 & 7.5 & 0.0 & 14.0 & 0.0 & 4.0 & 0.0 \\
\hline 4 & 0.0 & 0.0 & 0.5 & 0.0 & 0.0 & 1.0 & 0.5 & 0.0 & 1.0 & 0.0 & 0.5 & 0.0 \\
\hline 5 & 0.0 & 0.0 & 1.5 & 0.0 & 8.5 & 1.0 & 3.0 & 0.0 & 1.0 & 0.0 & 1.5 & 0.0 \\
\hline 6 & 1.0 & 1.0 & 0.5 & 0.0 & 0.0 & 1.5 & 0.5 & 0.0 & 0.0 & 0.0 & 1.0 & 0.0 \\
\hline 7 & 0.0 & 2.5 & 1.5 & 0.0 & 0.0 & 0.0 & 0.5 & 0.0 & 1.5 & 0.5 & 2.0 & 0.0 \\
\hline 8 & 0.0 & 0.0 & 1.5 & 0.0 & 0.0 & 2.0 & 1.5 & 0.0 & 0.0 & 0.0 & 4.5 & 0.0 \\
\hline 9 & 0.0 & 0.0 & 2.0 & 0.0 & 0.0 & 1.5 & 0.5 & 0.0 & 0.5 & 0.0 & 2.0 & 0.0 \\
\hline 10 & 0.0 & 0.0 & 0.5 & 0.0 & 0.0 & 0.0 & 2.5 & 0.0 & 0.0 & 0.0 & 1.0 & 0.0 \\
\hline 11 & 0.0 & 0.0 & 0.5 & 0.0 & 0.0 & 1.0 & 1.0 & 0.0 & 0.5 & 0.0 & 4.5 & 0.0 \\
\hline 12 & 0.5 & 0.0 & 0.5 & 0.0 & 0.0 & 0.0 & 1.0 & 0.0 & 0.5 & 2.0 & 0.0 & 0.0 \\
\hline 13 & 0.5 & 0.0 & 0.5 & 0.0 & 0.0 & 0.0 & 1.0 & 0.0 & 0.5 & 0.0 & 1.5 & 0.0 \\
\hline 14 & 0.0 & 0.0 & 25.0 & 0.0 & 18.5 & 3.0 & 0.0 & 0.0 & 0.0 & 0.0 & 0.5 & 0.0 \\
\hline Overage $^{2}$ & 0.25 & 0.71 & 1.08 & 0.00 & 1.58 & 0.79 & 1.38 & 0.00 & 0.58 & 0.21 & 1.92 & 0.00 \\
\hline
\end{tabular}

${ }^{1} 1$-hopper; 2-after pre-cleaning; 3-discard one; 4-after cleaning; 5 to 7-after sieve classifiers; 8 to 10 -after spiral separator; 11 to 13 -after gravity table; 14 discard two; ${ }^{2}$ not considering the samples from discard (3 and 14).

\section{Principal Components Analysis (PCA)}

In relation to variable behavior as a function of processing stages, the discard samples (3 and 14) had lower values of physical purity, germination, viability and vigor, and larger masses of sclerotia. The physical purity increased from stage 1 to 2 , remaining practically constant from the cleaning stage (4) until the end of processing. The values of germination, viability and vigor increased, with small changes during the processing line (Tables 1 and 2).

In both crop seasons, the percentage of variance accumulated in the first two PC was superior to $80 \%$. According to PCA cultivars, the pre-cleaning procedure was efficient in the removal of sclerotia, together with the other processing stages. In addition, after the classification stages, the samples made a homogeneous group with a high correlation with the physical and physiological quality of seeds (Figures 1 and 2).

In the 2009/2010 crop season, for cultivar NA 7255 $\mathrm{RR}$, the paper roll method was more efficient to detect the fungus in seeds in the discard stage sample (14). For cultivar NS 7476, it was in sample 3 that a greater incidence of fungus was detected by paper roll. In sample 14, that had no sclerotia, was detected a greater incidence of fungus by the neon method, compared with others; however, this was not detected by paper roll. In cultivar AN 8500, the samples 
9, 11 and 12 correlated with the neon method due to the fact that fungus incidence was detected in those samples by this method. In the same way as in cultivar A 7002, in BRS Valiosa RR the fungus was not detected by those seed heath tests and, therefore, they were not included in the PCA
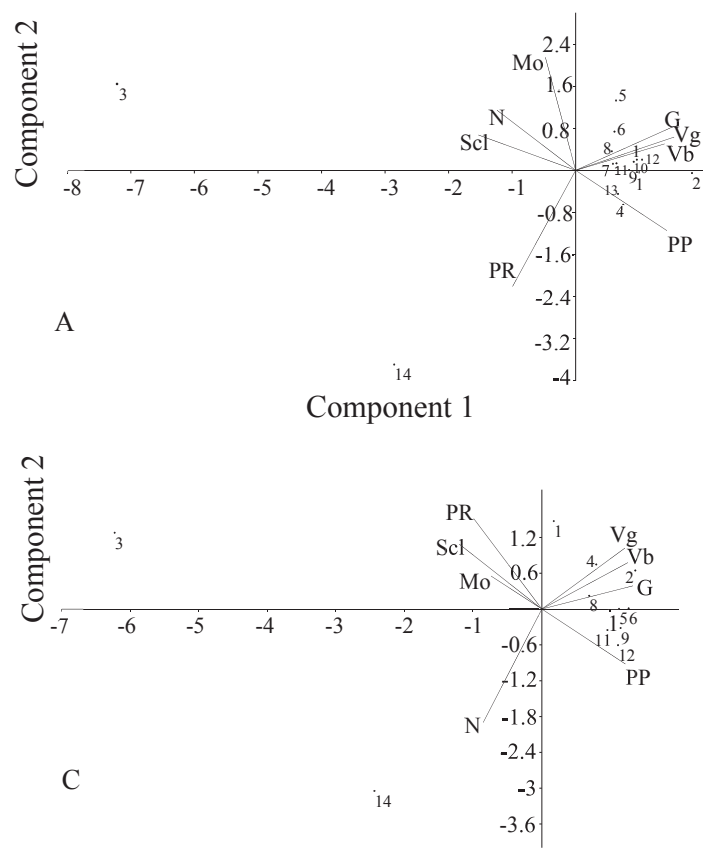

Component 1

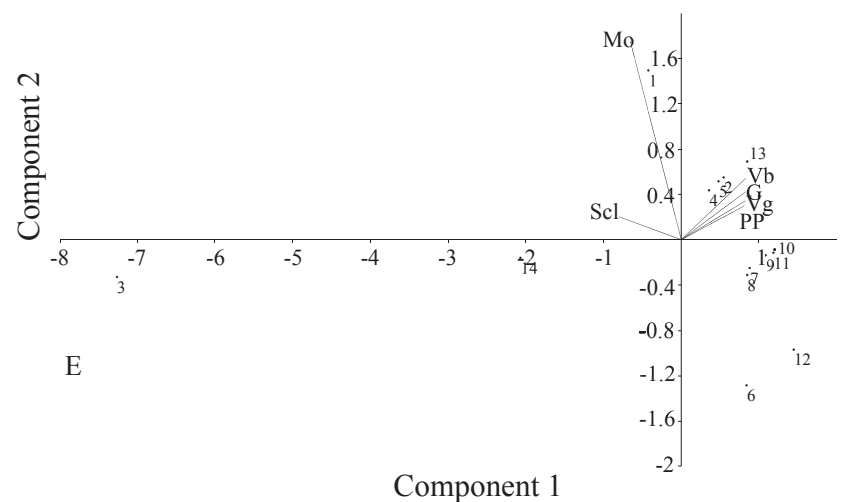

analysis (Figure 1). In crop season 2010/2011, sample 3 correlated more with paper roll (NA 8015 RR, BRS Valiosa RR and AN 8500), while in cultivars NA 7337 RR and NA $7620 \mathrm{RR}$, it was sample 14 that correlated more with this method (Figure 2).
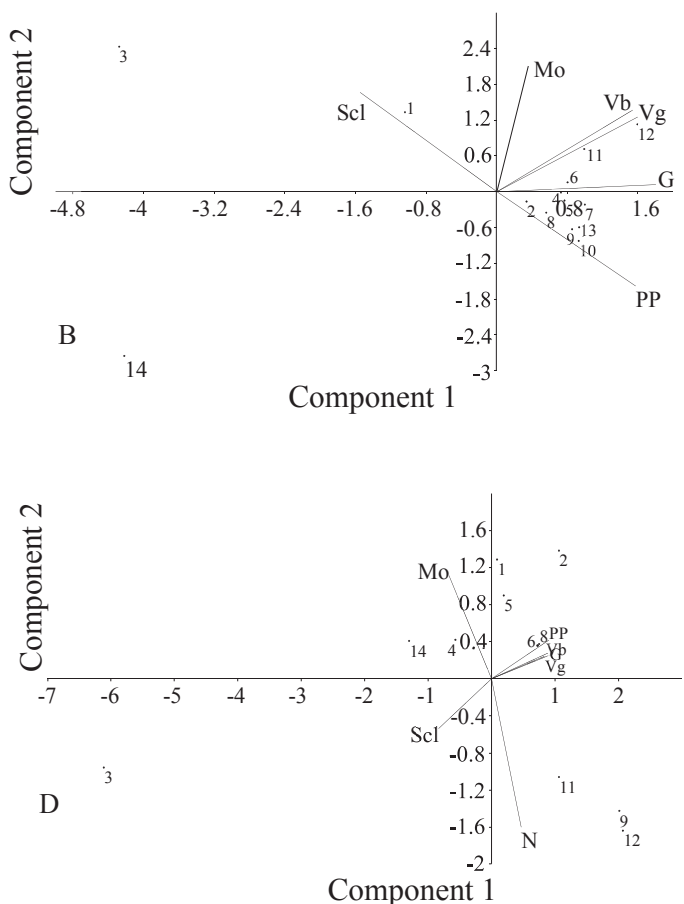

\begin{tabular}{l|l|} 
Scl: sclerotia & \\
G: germination & \\
N: test in neon medium & \\
PP: physical purity & \\
PR: test in paper roll & \\
Mo: moisture & \\
Vb: viability & \\
Vg: vigor & \\
\hline & \\
\hline 1: hopper & 8: spiral \\
2: pre-cleaning & 9: spiral \\
3: discard 1 & 10: spiral \\
4: cleaning & 11: gravity table \\
5: sieve classifier & 12: gravity table \\
6: sieve classifier & 13: gravity table \\
7: sieve classifier & 14: discard 2 \\
\hline
\end{tabular}

Figure 1. Ordination diagram by Principal Components Analysis (PCA) with stages of processing of soybean seeds from cultivars NA 7255 RR (A), A 7002 (B), NS 7476 (C), AN 8500 (D) and BRS Valiosa RR (E), crop season 2009/2010, and variables of physical and physiological qualities and Sclerotinia sclerotiorum incidence.

With these analyses, for the two crop seasons, it was observed that most of the processing stages, for each cultivar, had a high correlation with those variables (Figures 1 and 2). The values of physical purity, germination, viability and vigor correlated positively between themselves and negatively with sclerotia mass, that is, the larger the sclerotia mass combined with seeds, the lower the values of those variables were.
Furthermore, a larger sclerotia mass does not necessarily correspond to a larger incidence of white mold in seeds because in some cultivars (A 7002, AN 8500 and BRS Valiosa $\mathrm{RR}$ ), even having sclerotia in seed samples, there was no detection of fungus by the two methods.

In seeds of a single sample, although different results were found by both methods, these had a sensitivity to $S$. 
sclerotiorum detection and, consequently, the applicability in routine analysis.

The sample 3 correlated with the sclerotia mass in all cultivars of the 2010/2011 crop season (Figure 2) and in A 7002, NS 7476, AN 8500 and BRS Valiosa RR (Figure 1) from the 2009/2010 crop season; the same happened with sample 14 in cultivars A 7002 and BRS Valiosa RR (crop season 2009/2010) and NA 7255 RR (crop season 2010/2011). Moreover, there was a negative correlation of S. sclerotiorum incidence detected by the paper roll method with physical purity, germination, viability and vigor for four cultivars (NA 7255 RR, NA 7337 RR, NA 8015 RR and AN 8500), and a positive correlation of those methods with sclerotia mass, except in cultivar NA 7337 RR.

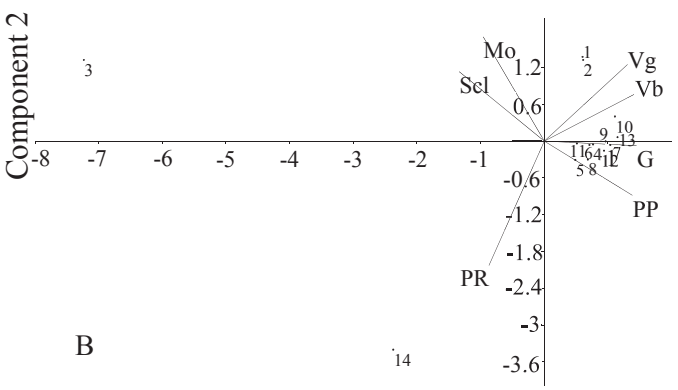

Component 1
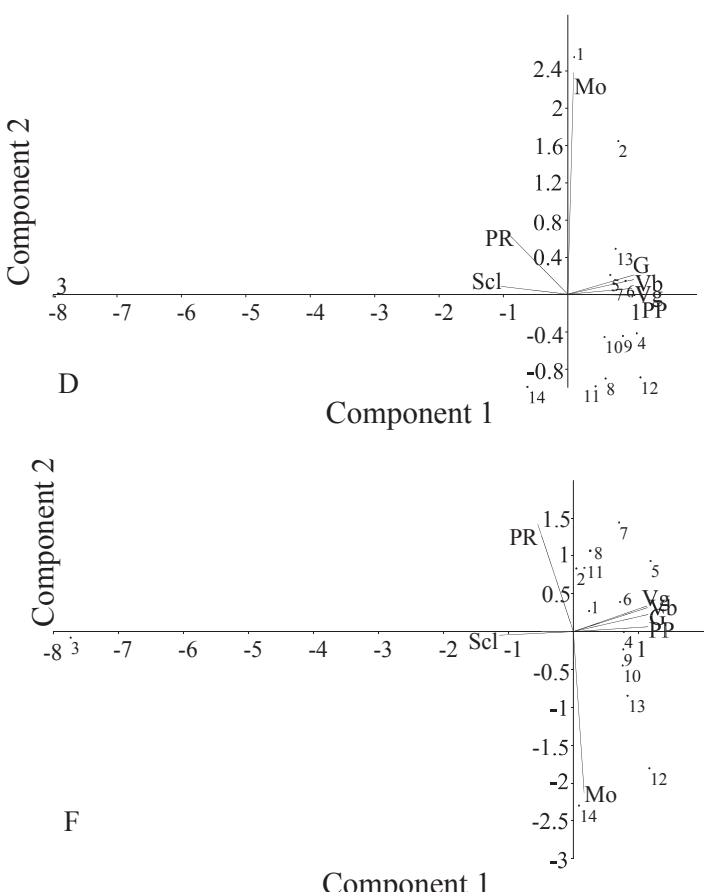

Component 1

\begin{tabular}{|ll|} 
1: hopper & 8: spiral \\
2: pre-cleaning & $9:$ spiral \\
3: discard 1 & 10: spiral \\
4: cleaning & 11: gravity table \\
5: sieve classifier & 12: gravity table \\
6: sieve classifier & 13: gravity table \\
7: sieve classifier & 14: discard 2 \\
\hline
\end{tabular}

Figure 2. Ordination diagram by Principal Components Analysis (PCA) with the stages of processing of soybean seeds from cultivars NA 7255 RR (A), NA 7337 RR (B), NA 7620 RR (C), NA 8015 RR (D), AN 8500 (E) and BRS Valiosa RR (F), crop season 2010/2011, and variables of the physical and physiological qualities and Sclerotinia sclerotiorum incidence. 
It is perceived that the response of each cultivar to postharvest handling is distinct, needing to be studied not only for its effects, but also its causes under different approaches. This will allow for the identification of the type, intensity and moment of an action that is able to affect the seed quality, mainly the sanitary quality.

In 2009/2010, the pathogen was not detected in the soybean seeds of cultivar BRS Valiosa RR by any of the sanity methods used; contrary to what was observed in the 2010/2011 crop season, when it was detected by paper roll. The cultivar NA 7255 RR had a larger infection percentage, considering the two methods used in 2010/2011, and AN 8500 had no infected seeds in 2009/2010 by paper roll, occurring on the next crop.

Napoleão et al. (2006b) also observed differences working with bean cultivars in different cropping seasons. The cultivar Diamante Negro had infected seeds in the first evaluated year, in the second year this happened only to cultivar Pérola. The author presumes that seed infection happens randomly. However, in this work, other factors may also be influencing fungus detection, since the cultivars are submitted to different field conditions (uncontrolled conditions) that strongly influence the seeds infection, mainly climatic conditions.

In fact, it was observed that, on both crops and in different cultivars, processing may be a useful tool to control this pathogen, since it can reduce or eliminate the sclerotia associated with them. With that, the processing may help to reduce the amount of inoculum that might be introduced in planting areas.

\section{Conclusions}

The processing of soybean seeds improves the lot quality in terms of physical purity, germination, viability and vigor, in addition to eliminating the sclerotia of S. sclerotiorum.

The pre-cleaning and cleaning stages, performed by the air-screen machines, significantly reduce the amount of sclerotia from soybean seeds.

The amount of sclerotia in the sample is not necessarily correlated to $S$. sclerotiorum incidence in mycelial form in seeds.

Not all of the seeds with seedborne S. sclerotiorum, incidence in dormant internal mycelial form are discarded by processing. Seeds with incipient infections may not be eliminated during seed processing and consequently they could be taken to the new field.

\section{References}

BOLTON, M.D.; THOMMA, B.P.H.J.; NELSON, B.D. Sclerotinia sclerotiorum (Lib.) de Bary: biology and molecular traits of a cosmopolitan pathogen. Molecular Plant Pathology, v.7, n.1, p. 1-16, 2006. http://library. wur.n1/WebQuery/wurpubs/346021

BRASIL. Ministério da Agricultura, Pecuária e Abastecimento. Instrução Normativa $\mathrm{n}^{\circ} 25$ de 16 de dezembro de 2005. Diário Oficial da União: Brasília, seção 1, p.18-26, 20 de dezembro de 2005.

BRASIL. Ministério da Agricultura, Pecuária e Abastecimento. Manual de análise sanitária de sementes. Ministério da Agricultura, Pecuária e Abastecimento Secretaria de Defesa Agropecuária. Brasília: MAPA/ACS, 2009a. 200p. http:// www.agricultura.gov.br/arq editor/file/12261 sementes -web.pdf.

BRASIL. Ministério da Agricultura, Pecuária e Abastecimento. Regras para análise de sementes. Ministério da Agricultura, Pecuária e Abastecimento. Secretaria de Defesa Agropecuária. Brasília: MAPA/ACS, 2009b. 395p. http://www.agricultura.gov.br/arq_editor/file/laborat\%c3\%b3rio/sementes/ regras $\% 20$ para $\% 20$ analise $\% 20 \mathrm{de} \% 20$ sementes.pdf

CONAB. Companhia Nacional de Abastecimento. Acompanhamento de safra brasileira: grãos, décimo segundo levantamento, Brasília: Conab, 2012. 30p. Accessed on: Sep. $17^{\text {th }} 2012$.

COSTA, P.; CUSTÓDIO, C.C.; MACHADO NETO, N.B.; MARUBAYASHI, O.M. Estresse hídrico induzido por manitol em sementes de soja de diferentes tamanhos. Revista Brasileira de Sementes, v.26, n.2, p. 105-113, 2004. http:// www.scielo.br/pdf/rbs/v26n2/24496.pdf

FESSEL, S.A.; SADER, R.; PAULA, R.C.; GALLI, J.A. Avaliação da qualidade física, fisiológica e sanitária de sementes de milho durante o beneficiamento. Revista Brasileira de Sementes, v.25, n. 2, p.70-76, 2003. http://www.scielo.br/ scielo.php?pid $=$ S010131222003000400010\&script $=$ sci_arttext

FRANÇA-NETO, J.B.; KRZYZANOWSKI, F.C.; COSTA, N.P.D. O teste de tetrazólio em sementes de soja. Londrina: Embrapa-CNPSo, 1998. 72p. (Embrapa-CNPSo. Documentos, 116).

GADOTTI, G.I.; CORRÊA, C.L.; LUCCA FILHO, O.; VILLELA, F.A Qualidade de sementes de couve brócolis beneficiadas em mesa densimétrica. Revista Brasileira de Sementes, v.28, n.2, p.123-127, 2006. http:// www.scielo.br/scielo.php?script=sci_arttext\&pid=S0101-31222006000 $200016 \& \operatorname{lng}=$ pt\&nrm $=$ iso $\&$ tlng $=$ pt

GIOMO, G.S.; NAKAGAWA, J.; GALLO, P.B. Beneficiamento de sementes de café e efeitos na qualidade fisiológica. Bragantia, v.67, n.4, p.1011-1020, 2008. http://www.scielo.br/pdf/brag /v67n4/25.pdf.

GIOMO, G.S.; RAZERA, L.F.; GALLO, P.B. Beneficiamento e qualidade de sementes de café arábica. Bragantia, v.63, n.2, p.291-297, 2004. http://www. scielo.br/scielo.php?script=sci_arttext\&pid=S0006-87052004000200014

HAMMER, O.; HARPER, D.A.T.; RYAN, P.D. PAST: Paleontological Statistics Software Package for Education and Data Analysis. Palaeontologia Electronica v.4, n.1, p.9, 2001. http://palaeo-electronica.org/2001_1/past/past.pdf

MERTZ, L.M.; HENNING, F.A.; MAIA, M.S.; MENEGHELlO, G.E.; HENRIQUES, A.; MADAIL, R. Qualidade fisiológica e sanitária de sementes de feijão-miúdo beneficiadas em mesa gravitacional. Revista Brasileira de Sementes, v.29, n.3, p.1-8, 2007. http://www.scielo.br/scielo .php?script=sci arttext\&pid=S010131222007000300001\&lng=pt\&nrm=iso\&tlng=pt 
NAPOLEÃO, R.; NASSER, L.C. B.; LOPES, C.A.; CAFÉ FILHO, A.C. Neon-S, um novo meio de detecção de Sclerotinia sclerotiorum em sementes. Summa Phytopathologica, v.32, n.2, p. 180-182, 2006a. http://www.scielo.br/ scielo.php?script=sci_arttext\&pid=S0100-54052006000200014

NAPOLEAO, R.; CAFE FILHO, A.C.; LOPES, C.A.; NASSER, L.C.B. Efeito do espaçamento e da cultivar de feijoeiro sobre a intensidade do mofo-branco e a sanidade de sementes. Summa Phytopathologica, v.32, n.1, p.63-66, 2006b. http:// www.scielo.br/scielo.php?pid=S0100-54052006000100009\&script=sci_arttext

NERY, M.C.; CARVALHO, M.L.M.; OLIVEIRA, J.A.; KATAOKA, V.Y. Beneficiamento de sementes de nabo forrageiro. Revista Brasileira de Sementes, v.31, n.4, p.36-42, 2009. http://www.scielo.br/scielo. php?script=sci_arttext\&pid=S010131222009000400004\&lng=en\&nrm=iso

PÁDUA, G.P.; ZITO, R.K.; ARANTES, N.E.; FRANÇA-NETO, J.B. Influência do tamanho da semente na qualidade e na produtividade da cultura da soja. Revista Brasileira de Sementes, v.32, n.3, p.09-16, 2010. http://www. scielo.br/pdf/rbs/v32n3/v32n3a01.pdf

PALMER, M.W. Putting things in even better order: the advantages of canonical correspondence analysis. Ecology, v.74, n.8, p.2215-2230, 1993. http://www.jstor.org /stable/1939575
PERIN, A.; ARAÚJO, A. P.; TEIXEIRA, M. G. Efeito do tamanho da semente na acumulação de biomassa e nutrientes e na produtividade do feijoeiro. Pesquisa Agropecuária Brasileira, v.37, n.12, p.1711-1718, 2002. http://www.scielo.br/pdf/pab/v37n12/14637.pdf

TER BRAAK, C.J.F. Cannonical correspondende analysis: a new eigenvector technique for multivariate direct gradient analysis. Ecology, v.67, n.5, p.1167-1179, 1986. http://www.jstor.org/discover/10.2307/1938672?ui$\mathrm{d}=3737664$ \&uid $=2129$ \&uid $=2$ \&uid $=70$ \&uid $=4 \&$ sid $=21101336956843$

TU, C. The role of mold-infected white bean (Phaseolus vulgaris L.) seeds in the dissemination of Sclerotinia sclerotiorum de Bary. Journal of Phytopathology, v.121, n.1, p.40-50, 1998. http://agris.fao.org/agrissearch/ search/display.do?f=1988\%2FDE\%2FDE88091.xml\%3BDE88U014888

VANDERPLANK, J.E. Plant diseases: epidemics and control. New York: Academic Press, 1963. 349p. 